вневедомственной охране», «О частной детективной деятельности» в РФ» и в ряде других

Федеральный закон «О государственной обороне» также запрещает применение оружия в отношении лиц, с явными признаками инвалидности и несовершеннолетних, если их возраст очевиден или известен сотруднику. Но также делается уточнение, что оружие можно применять в случае оказания ими вооруженного сопротивления, совершения вооруженного либо группового нападения, угрожающего жизни людей.

Следовательно, применение оружия против общественно опасного посягательства, совершенного несовершеннолетним и невменяемым не противоречит ст. 37 ч. 1 УК РФ в которая регламентирует, что причинение вреда посягающему допускается, если посягательство было совершено с насилием, опасным для жизни обороняющего или с непосредственной угрозой применения такого насилия.

$$
* * *
$$

1. Закон РФ от 11. 03. 1992 № 2487-1 (ред. от 05.12.2017) «О частной детективной и охранной деятельности в Российской Федерации» // Российская газета. 30.04.1992.

2. Наумов А.В. Российское уголовное право. Общая часть: Курс лекций. М.: 1996. С.329; Тишкевич И.С. Условия и пределы необходимой обороны. М.: 1996.

3. Необходимая оборона, крайняя необходимость, задержание преступника (правовая оценка действий сотрудников полиции) / С.В. Борисов, А.П. Дмитриенко, Е.А. Русскевич и др.; отв. ред. Н.Г. Калников. М.: 2012. С.122

4. Орехов В.В. Необходимая оборона и иные обстоятельства, исключающие преступность деяния. СПб.: 2003. С.54.

5. Российская газета. 3 октября 2012.

6. Ткачевский Ю.М. Институт необходимой обороны // Вестник Московского университета. Серия 11. Право. 2003. № 1.

7. Шавгулидзе Т.Г. Необходимая оборона. // Тбилиси. 1996.

8. Федеральный закон от 13.12. 1996 № 150-3 (ред. от 29.12.2017) «Об оружии» (с измен.и доп., вступ. в силу с 01.01. 2018) Ст. 24. // Российская газета. 18.12. 1996. Ст. 24.

9. Федеральный закон от 14.04.1999 № 77-Ф3 (ред. от 05.12.2017) «О вневедомственной охране» Ст. 16. // Российская газета. 20.04.1999.

10. Федеральный закон от 27.05.1996 № 57-ФЗ (ред. от 01.07.2017) «О государственной охране» Ст. 27.п.3 // Российская газета. 06.06. 1996.

11. Федеральный закон от 07.02. 2011 № 3-Ф3 (ред. от 05.12. 2017) «О полиции»//Российская газета 10.02.2011.

\title{
Гуков А.Э. \\ Разграничение понятий свободы мысли и слова. Роль свободы мысли и слова в российском обществе
}

Орловский Государственный Университет имени Ивана Сергеевича Тургенева (Россия, Орёл)

doi:10.18411/lj-31-03-2018-60

idsp: 000001:lj-31-03-2018-60

\section{Аннотация}

Право на свободу мысли и слова - схожие и взаимосвязанные между собой понятия. Однако, каждое из данных понятий имеют своё предназначение, функции, характеристику. Предлагаемая читателю статья раскрывает понятия свободы мысли и свободы слова вместе и врознь, а также дает общее понятие об их роли в современных российских реалиях.

Ключевые слова: свобода мысли, свобода слова, Конституция, права человека, государство, общество.

Нам известно, что статья 29 Конституции РФ закрепляет право граждан на свободу мысли и слова. Из этой статьи следует, что «разрешено всё то, что прямо не запрещено 
законом». В свою очередь, данный постулат определяет то, что человек имеет право выражать свои мысли посредством статей, художественных рисунков, литературных произведений, музыкальные композиции, показывая направленность своих взглядов, суждений, мнений, оценок и прочего. Соответственно, и восприятие перечисленных сведений человеком происходит с его мыслей, которые выражаются посредством слова.

Стоит отметить, что слово и мысль имеют много общего, однако их стоит разграничивать. Слово - это продолжение мысли, инструмент ее закрепления. Мысль же - это внутренний продукт человека, продукт его духовного мира, его интеллектуальной работы. Поэтому слово - является внешним проявителем мысли. А мысль, в свою очередь имеет внутренний акцент. И здесь должным образом стоит выделить то, что мысль является объектом внутреннего мира человека и его интеллектуальной работы, что фактически не поддается правовому регулированию.

Как известно, в сферу правового регулирования попадает только внешнее поведение. Так как государство не может предоставить человеку лояльные условия для комфорта его внутреннего мира внутри, то оно обязано сделать это извне. А так как слово - это инструмент для выражения мысли, то на государство возложена обязанность для наиболее комфортного доступного и полноценного выражения человеком своих мыслей через слово в рамках закона.

Свободу мысли и слова можно разграничить по внешнему и внутреннему признаку. Свобода слова может проявляться как индивидуально, так и публично. Мысль же сперва формируется внутри и только потом может быть высказана с помощью слова.

Статья 10 Европейской Конвенции о защите прав человека и основных свобод определяет право человека на свободное выражение своего мнения без какого-либо вмешательства со стороны государственных лиц или публичной власти. Конституция Российской Федерации также содержит норму о праве индивидов на свободное получение распространение информации.

Часть 4 статьи 29 Конституции Российской Федерации указывает на то, что каждый имеет право на свободное получение, распространение, хранение, передачу информации любым методом, отвечающим нормам закона. Однако, исходя из иной точки зрения, данная норма пересекается с правом на свободу мысли и слова, но может составлять отдельную конституционную норму.

Информация - это особый материал, производимый человеком на основе его личностных взглядов, убеждений, мнений и интересов, который отражается в том или ином виде - словах, статьях, произведениях и прочем - что, в свою очередь, представляет собой данные с личностным окрасом, которые отражают конкретную позицию.

Стоит отметить, что мысль и слово - понятия более широкие, чем информация. Информация - это лишь некий «строительный материал», с которым работает человек, основываясь на более широких категориях мысли и слова. Мысль и слово помогают созидать и облагораживать данный материал, придавая ему персональный оттенок, который строится на основе личностных мнений и позиций конкретного индивида.

Право поиска информации заключается в праве человека не только на свободный поиск интересующего материала субъектом права.

Далее следует выделить и иные критерии права поиска информации:

- Право на приобретение в собственность и владение определенной информацией в целях ее дальнейшего использования и распространения;

- Право производить информацию - подразумевает право человека на выработку каких-либо сведений - массовых (которые предназначаются для неопределенного круга лиц) или индивидуальных;

- Право на передачу информации - человек имеет право приобретать, владеть информацией, передавать имеющуюся информацию в пользование для других заинтересованных лиц или организаций, от своего имени, либо без такового; 
- Право на распространение информации - данное право предполагает возможность индивида передавать принадлежащую ему информацию во владение от себя или иного субъекта, право на пользование принадлежащей ему информации неограниченному кругу лиц.

Стоит помнить, что право человека на распространение, передачу и хранение информации осуществляется в строгом соответствии с действующим законодательством.

Следует также отметить, что свобода слова не может быть абсолютной и безграничной, каким бы это право не было бы важно для реального проявления свобод человека в прогрессивном демократическом государстве.

Здесь стоит заметить, что в этом состоит одно из главных различий между правом на свободу мысли и правом на свободу слова. Так как мысль является продуктом интеллектуального труда человека, его духовного внутреннего мира - то, соответственно, она не попадает под рычаги правового регулирования. Как уже указывалось выше - слово - это инструмент для выражения мысли. Но право на свободу слова уже попадает во внешнюю сферу, являясь объектом общественных отношений, что, в свою очередь, является объектом правового регулирования. Поэтому индивид фактически имеет безграничное право на свободу мысли, однако, выражая свою мысль посредством права на свободу слова, обязан следовать рамкам закона, подводя свою мысль под действующее законодательство, не нарушая его норм.

Мысль по своей сути неконтролируема и не подлежит какому-либо регулированию. А слово во все времена оказывало сильнейшее воздействие как на конкретных людей, так и на целые массы. Слово может как и приносить пользу обогащать внутренний мир человека, давать знания, призывать к прогрессу, так и совершенно наоборот - призывать к насилию, унижению человеческого достоинства, оскорблениям и клевете.

В данном положении также стоит учитывать и то, каково мировоззрение человека, его устоявшиеся принципы, знания, мнения и взгляды - так и будет он использовать свое юридическое право на свободу мысли. Индивид может поддаться на провокации, может отнестись скептически, может принять информацию, независимо от ее эмоционального оттенка. А как он это проявит - зависит от его поведения и того, как он распорядится своим правом на свободу слова.

Соответственно, существует необходимость разграничения рамок дозволения, касательно права на свободу слова. Исходя из различий людей по самым разнообразным признакам - мировоззрение, менталитет, взгляды, позиции, мнения - право на свободу слова ограничивается некоторыми нравственными и правовыми рамками.

Как уже было сказано, Конституция РФ дает гражданам право на свободу слова, однако, исключает агитацию или пропаганду, связанную с расовым, национальным, религиозным, социальным, языковым и прочим превосходством. Иными словами данная норма запрещает подрыв общественного согласия различными суждениями, основанными на вражде по различным признакам.

Роль свободы мысли и слова в российском обществе имело изначально различные предпосылки. Весь цивилизованный мир во второй половине двадцатого столетия стремительно переходил к всеобщей гласности, равенству и расширенному списку прав и свобод человека, без которых не могли полноценно функционировать правовое государство и гражданское общество.

В восьмидесятые годы прошлого столетия Советский Союз по примеру западных коллег начал проводить политику гласности под руководством генерального секретаря ЦК КПСС Михаила Сергеевича Горбачева.

Политика гласности включала в себя следующие реформы, направленные на демократизацию общества:

- Существенное ослабление цензуры и снятие информационных барьеров; 
- Прекращение замалчивания возникающих проблем на местах;

- Допустимость различных митингов, в которых обсуждалась политика гласности;

- Право на выбор пути общественного развития - в основном, обсуждалось в печатных изданиях;

- Возникали разнообразные общественные объединения, целью которых была поддержка политики гласности;

Существовало еще множество нюансов, связанных с расширением свобод в советском обществе - народные гуляния в 1988 году в честь 1000-летия крещения Руси, создание новых религиозных объединений, амнистирование жертв репрессий со времен правления И.В. Сталина, создание различных телевизионных программ, печатных изданий, которые могли критиковать власть, и, конечно же, снятие «железного занавеса», который позволил советским гражданам увидеть жизнь западного мира.

Было бы некорректно сказано, что политика гласности дала гражданам полную свободу, однако, стоит учесть то, что данных свобод обществу хватило, чтобы государство не смогло с этим справляться и пустило всё на самотек.

С распадом Советского Союза, в Российскую Федерацию пришла демократия и рыночная экономика, которые требовали полноправия, но при этом и равноправия граждан. Произошла либерализация рынка, была принята новая Конституция Российской Федерации от 12.12.1993 года, которая практически в неизменном виде существует и до сих пор.

Изменения в правовой сфере для российского общества были неизбежны по множеству факторов:

- Переход к новому типу экономики, либерализация рынка, свободный денежный оборот;

- Новый государственный режим - демократия, который предполагает защиту и стимулирование прав и свобод человека и гражданина, подразумевает построение прогрессивного гражданского общества в правовом государстве;

- Новая форма правления - президентская республика, которая подразумевает под собой избрание гражданами государственной власти на конкретный срок;

И это только основные факторы, повлиявшие на изменения в правовой, общественной, государственной, социальной сферах, которые прямо бросаются в глаза.

Однако нас интересует, в первую очередь, право на свободу мысли и слова и его роль в российском обществе.

Право на свободу мысли и слова с приходом нового времени сначала воспринимались двояко. Одни утверждали, что это шаги в сторону цивилизованного мира, новый прогрессивный путь развития, первые шаги на пути к построению гражданского общества в правовом государстве. Другие же отмечали, что вседозволенность порождает пороки в обществе, столкновение различающихся по себе между собой групп (национальных, религиозных, политических и пр.), социальный подрыв и другие проблемы.

Стоит заметить, что понятие свободы слова небезгранично, и это указано на государственном уровне в Конституции Российской Федерации. Резкий переход от тоталитарного общества к демократическому не каждому дал возможность сразу «перестроиться» на новый лад.

Безусловно, право на свободу мысли и слова - заметное достижение для российского общества. Данное право помогает взглянуть на происходящее с разных сторон, точек зрения, позволяет проявить критическое мышление, свою позицию, выразить своё мнение. 
Свобода мысли и слова является одним из проявлений воли народа, так как к данной норме, в той или иной мере можно отнести:

- Право высказывать свою политическую позицию;

- Право освещать события в стране, проблемы, связанные с ситуацией в государстве;

- Право на критику власти;

- - Избирательное право. В той или иной мере - это проявление права на свободу мысли через избирательный инструмент. Индивид, исходя из собственных соображений, позиции, мнения имеет право выбрать наиболее подходящего для себя кандидата в президенты (или представителей партии в Государственную Думу), либо не участвовать в выборах вообще;

- Право на создание политической партии. Исходя из права на свободу мысли и слова, можно утверждать, что партия создается из каких-либо суждений, политической позиции лидера партии и примкнувших к нему единомышленников. Тем самым они реализуют свое право на свободу слова, выдвигая свои лозунги, политику партии, социально-экономическую программу и прочее, что изначально исходит из их мыслей.

Право на свободу мысли и слова в той или иной мере пересекается с другими правами человека в Российской Федерации. Для построения прогрессивного гражданского общества требуется данное право, которое ограничено нравственными и юридическими рамками, чтобы исключить проявления экстремизма, вражду и негативные настроения в обществе.

С помощью свободы слова, исходя из вышеперечисленных пунктов, граждане могут критиковать власть, тем самым влияя на правительство. Свободные СМИ имеют право освещать «горячие» для государства темы, тем самым подталкивая власть к решению проблемы.

В пример можно привести активную деятельность журналистов и военных корреспондентов, которые освещали события, происходившие во время Первой Чеченской Кампании. Благодаря освещению тех событий для общества в крупных государственных проблемах в Северо-Кавказском Федеральном Округе комитет солдатских матерей, созданный еще при М.С. Горбачеве, развернул свою деятельность на территории всей Российской Федерации, помогавший и помогающий по сей день решать существующие проблемы в рядах вооруженных сил России.

Право на свободу мысли и слова - это не только дозволение «всего, что не запрещено законом» или шаг к построению гражданского общества. Это также рычаг для решения многих государственных, социальных, экономических и прочих проблем государства. С помощью свободы слова в жизни страны участвуют не только государственные органы, но и население.

$$
* * *
$$

1. Конвенция о защите прав человека и основных свобод (Заключена в г. Риме 04.11.1950) (с изм. от 13.05.2004) (вместе с "Протоколом [N 1]" (Подписан в г. Париже 20.03.1952), "Протоколом N 4 об обеспечении некоторых прав и свобод помимо тех, которые уже включены в Конвенцию и первый Протокол к ней" (Подписан в г. Страсбурге 16.09.1963), "Протоколом N 7" (Подписан в г. Страсбурге22.11.1984))

2. Конституция Российской Федерации (принята всенародным голосованием 12.12.1993) (с учетом поправок, внесенных Законами РФ о поправках к Конституции РФ от 30.12.2008 N 6-ФКЗ, от 30.12.2008 N 7-ФКЗ, от 05.02.2014 N 2-ФКЗ, от 21.07.2014 N 11-ФКЗ)

3. Баглай М.В. Конституционное право Российской Федерации - М.: Издательская группа НОРМА ИНФРА: М, 2008. - 752 с.

4. Клименко С.В., Чичерин А.Л. Основы государства и права: пособие для поступающих в вузы. - М.: Зерцало, 2014. - 354 c.

5. Косарева А.И. Права человека / Права человека в современных реалиях. - М.: ЮНИТИ, 2010. - 370 с. 
6. Кутафин О.Е. Основы государства и права: Учебное пособие для поступающих в вузы - 4-е изд., перераб. и доп. - М.: Юрист, 2006, - 360 с.

7. Новоселов Н.А. Учебник для юридических вузов и факультетов. - М.: Издательская группа ИНФРА*М - HOPMA, 2016. - 570 c.

8. Теплова Н.А. Право: Учебник. / Под ред. Н.А. Тепловой, М.В. Малинкович. — М.: ЮНИТИ, 2008. $306 \mathrm{c.}$

9. Есть ли свобода слова в России? // pr-agentstvo.com [Электронный ресурс]. - Режим доступа: https://pragentstvo.com/articles/mnenie-zhurnalistov-est-li-v-rossii-svoboda-slova.html (Дата обращения: 18.03.2018)

10. История комитета солдатских матерей // soldiers-mothers-rus.ru [Электронный ресурс]. - Режим доступа: http://www.soldiers-mothers-rus.ru/history.html (Дата обращения: 18.03.2018)

11. Разграничение понятий свободы мысли и свободы слова // isfic.info [Электронный ресурс]. - Режим доступа: http://isfic.info/konst/kokot51.htm (Дата обращения: 18.03.2018)

12. Перестройка в CCCP 1985-1991 гг. // fb.ru [Электронный pecypc]. - Режим доступа: http://fb.ru/article/225762/perestroyka---v-sssr-opisanie-prichinyi-i-posledstviya ～(Дата обращения: 18.03.2018)

13. Свобода слова. История и содержание // studwood.ru [Электронный pecyрс]. - Режим доступа: https://studwood.ru/520551/pravo/svoboda_slova (Дата обращения: 18.03.2018)

\section{Диденко А.Н. \\ Борьба с коррупцией как способ наполнения бюджета}

Пермский государственный наџиональный исследовательский университет

(Россия, Пермь)

doi:10.18411/lj-31-03-2018-61

idsp: 000001:lj-31-03-2018-61

\section{Аннотация:}

Проблема коррупции в последнее время приобрела огромную и вполне обоснованную актуальность. По уровню коррупции Россия относится к неблагополучным странам. Необходимость борьбы с коррупцией не подлежит сомнению. Однако у автора данной статьи возникают сомнения в соблюдении публичных и частных интересов при реализации одного из способов борьбы с коррупцией, а именно, административной ответственности за незаконное привлечение к трудовой деятельности либо к выполнению работ или оказанию услуг государственного или муниципального служащего либо бывшего государственного или муниципального служащего, т.е. с нарушением требований, предусмотренных Ф3 от 25 декабря 2008 года № 273-Ф3 «О противодействии коррупции». В данной работе анализируется правоприменительная практика борьбы с коррупцией на примере реализации ст.19.29 КоАП РФ, указывается на несправедливость привлечения к административной ответственности по данной статье ввиду отсутствия в большинстве случаев каких-либо коррупционных проявлений, и, кроме того, обосновывается прямая финансовая заинтересованность государства в сохранении существующего режима ответственности по ст.19.29 КоАП РФ, в том числе, вотказе от применения института малозначительности, что, в свою очередь, не позволяет рассматривать правоприменение данной статьи как меру предупредительного характера для борьбы с коррупцией, поскольку по своей сути оно является сугубо карательным.
Ключевые
слова:
административное
правонарушение,
коррупция,

малозначительность, государственная (муниципальная) служба, бюджет.

\section{Abstract:}

The problem of corruption has recently acquired a huge and well-founded relevance. The level of corruption, Russia is a dysfunctional countries. The necessity of the fight against corruption cannot be questioned. However the author of this article has doubts in observance of public and private interests at realization of one of ways of fight against corruption, namely, bringing to administrative responsibility for illegal attraction to labor activity or to performance of works or rendering services of the public or municipal employee or the former public or municipal employee, i.e. with violation of the requirements provided by FZ of December 25, 